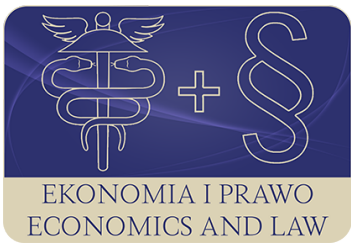

EKONOMIA I PRAWO. ECONOMICS AND LAW

Volume 19, Issue 3, September 2020

p-ISSN 1898-2255, e-ISSN 2392-1625

www.economicsandlaw.pl

EKONOMIA I PRAWO
ECONOMICS AND LAW

ORIGINAL ARTICLE

received 15.03.2020; revised 16.05.2020; accepted 30.09.2020

Citation: Kola-Bezka, M. (2020). Community-led local development in urban and other areas: lessons from Kujawsko-Pomorskie voivodship. Ekonomia i Prawo. Economics and Law, 19(3): 505-521. doi:10.12775/EiP.2020.034.

\title{
Community-led local development in urban and other areas: lessons from Kujawsko-Pomorskie voivodship
}

\author{
MARIA KOLA-BEZKA \\ Nicolaus Copernicus University in Torun, Faculty of Economic Sciences and Management, \\ Department of Economic Policy and Regional Studies, ul. Gagarina 13a, 87-100 Toruń, Poland \\ $\square$ mkola@umk.pl \\ (D) orcid.org/0000-0001-9532-8540
}

\begin{abstract}
Motivation: The study explores core outcomes of implementation of community-led local development (CLLD) in Kujawsko-Pomorskie voivodship, referring to the problem of reducing the scale of social exclusion.

Aim: Its aim was to compare the engagement of local action groups (LAGs) operating in urban and other areas in solving social exclusion problems.

Results: The study found that in the voivodship urban LAGs are generally much more involved in solving social exclusion problems than the other LAGs, but even in their case the effectiveness of planned pro-inclusive activities is low. The results suggest that the CLLD instrument tested in the largest cities of the voivodship in current financial perspective can be successfully used in other cities in Poland in forthcoming one. However,

the scope and effectiveness of planned social inclusion projects should be increased.
\end{abstract}

Keywords: community-led local development; local action groups; social inclusion; social exclusion; Kujawsko-Pomorskie voivodship

JEL: O18; R19; D79

\section{Introduction}

Community-led local development (CLLD) is one of the most important instruments of territorial development of the EU in the financial perspective 20142020. It consists of three key components: local action groups (LAGs), local 
development strategies (LDSs) prepared by them and their own designated areas covered by the strategies (Regulation, 2013). The functioning of local action groups, which are, in fact, area-based partnerships, has been tested in the European Community and later in the EU for over 20 years of implementation of the LEADER approach.

In 2014-2020 financial perspective CLLD is expected to facilitate the sustainable implementation of multi-dimensional and cross-sectoral interventions from all EU funds and is addressed to all EU areas (rural, urban, coastal etc.). Depending on the territory they concern, the actions implemented under CLLD may be financed from different EU funds and the instrument may be implemented using different methods. Both the rules regarding the financing and the methods of implementation of the instrument were set out in the partnership agreements of each Member Country. The Polish Partnership Agreement (Ministry of Infrastructure and Development, 2014) allowed for implementation of CLLD in rural areas under Rural Development Program 2014-2020 and in fisheries areas under Operational Program FISHERIES, under the European Agricultural Fund for Rural Development and the European Maritime and Fisheries Fund, respectively. CLLD might have been also supported from the European Social Fund and the European Regional Development Fund across the whole country under Regional Operational Programmes (ROPs), but depending on the decision of the voivodship authorities which decided not only which funds (both listed or only one of them) would have served CLLD, but also which of the following methods will be used to implement the instrument: direct, indirect or mixed. A direct method is to implement single fund or multi fund LDSs in the entire territory of a voivodship (including cities with the population exceeding 20,000). In this method in LDSs, at the moment of their selection, the indicative budget for projects implemented under LDS is specified. An indirect method is to support LAGs only in rural and fisheries areas, as selected for support from the EARDF and the EMFF as beneficiaries of regular axes, actions or sub actions under ROPs without specifying in their LDSs the indicative budget for projects. In the mixed method LAGs operating in rural and fisheries areas can be supported by the indirect method and LAGs operating in cities with the population exceeding 20,000 (or in selected districts of these cities) can be supported by the direct method.

In Poland in 2014-2020 the direct method of implementing of CLLD has only been used in two voivodships, namely the Podlaskie and Kujawsko-Pomorskie voivodship. In both voivodships in rural and fisheries areas, whereas in cities only in the latter. Given that in 2021-2027 financial perspective CLLD as a specific instrument of regional development (also in cities) is to be strengthened (mainly financially) and is to be even more important than in the current programming period (European Committee of the Regions, 2019), it is extremely crucial to know whether fundamental desired outcome of functioning of LAGs, i.e. social inclusion is implemented in practice. Also taking into account that, in practice, the implementation of CLLD is based on the imple- 
mentation of LDSs, it is reasonable to assess the degree of inclusiveness of these strategies which, in fact, testifies to the LAG's commitment to solving social exclusion problems.

The aim of the article is to compare the engagement of urban and other LAGs in the Kujawsko-Pomorskie voivodship in solving social exclusion problems. This knowledge shall be useful to develop the assumptions of implementation of CLLD in Polish voivodships in the forthcoming financial perspective, especially in those which do not have experiences in implementing CLLD in cities.

\section{Literature review}

In the EU in 2014-2020 funding period the idea of CLLD is a form of spreading of LEADER approach. LEADER started in 1991 as an experimental European Community Initiative and was applied in marginalized rural areas to bring forward their development. Since 2000 it has been extended to a wide range of rural regions. In 2007-2013 funding period it was mainstreamed into rural development programmes as a horizontal obligatory priority axis (Pollermann et al., 2014, p. 3). For the period 2014-2020 the EU introduced a newly-arranged structure for funding from its funds and provided all these funds with a set of basic rules in line with the general principles such as partnership, multi-level governance, equality and sustainability. After long-time experiences with the LEADER approach it is believed that the support of integrated local development strategies developed by local actions groups can facilitate the sustainable implementation of multi-dimensional and cross-sectoral interventions. Thus, CLLD is addressed not only to rural (as an obligatory measure), but all EU areas (to urban and coastal as an option) to foster new opportunities, socio-economic benefits, diversification of activities, networking and innovation (Birolo et al., 2012, pp. 39-55; Kołomycew, 2017, pp. 71-82).

A key element of CLLD are LAGs which develop LDSs. These are programmes frequently presented as a means of addressing social exclusion, both through the inclusive nature of the partnership structure, and through the local nature of the partnership, which is perceived to allow greater access to excluded groups than centralised policy (Shortall, 2004, p. 113). Enhancing the role of partnerships in local governance is hardly a new thought. The most significant growth in the number of partnerships globally was in the late 1980s and 1990s (Edwards et al., 2001, pp. 289-310; Esparcia Perez, 2000, pp. 200207; Hague, 2004, pp. 271-290). In developing countries, it was connected with the political, economic and social imperatives to mitigate rural poverty and empower local people in community development programmes (Kapoor, 2005, pp. 210-215). Here, governments were increasingly reducing their role from delivery to supporting and enabling roles commensurate with emerging ideas of community governance (Marshall, 2005). In Poland, in turn, the history of area-based partnerships is much shorter. Although entities representing various sectors of the economy may establish partnerships in this country from 
the early 1990s, organized groups of such entities in rural areas on a larger scale began to be created almost 10 years later. However, in the years 2000-2004 territorial partnerships in Poland were not created entirely according to the bottom-up approach, on the own initiative of the inhabitants of a given area, but were usually popularized and implemented as part of foreign programs through national NGOs or in response to the possibility of obtaining funds from these programs (Furmankiewicz, 2006, pp. 117-136). It was only accession to the EU in 2004 that became highly significant for the development of bottom-up area-based partnerships in rural Poland. However, for quite a long time the national government was reluctant to use these partnerships more widely than for village renewal activities (Furmankiewicz et al., 2010, pp. 52-62). In the 20142020 financial perspective, as in other Member Countries, LAGs are to play a crucial role in local development. The implementation of CLLD and the functioning of LAGs in Poland are regulated in the Act on local development (2015) with the participation of the local community.

LAGs being area-based partnerships include representatives of public and private local socio-economic interests. In the expanding literature on partnerships, both positive and negative aspects of their creation and functioning in local communities can be found. Referring to the former, Scott (2012, pp. 1-2) mentions that partnerships can be perceived as universal goods and institutions providing additionality (i.e. their whole is greater than their parts) (Roberts, 2003, pp. 1-69). They can be also perceived as flexible tools in managing change (Rosenau, 2000), reducing uncertainty (Stoker, 1998, pp. 17-28), improving co-ordination (Davidson \& Lockwood, 2008, pp. 641-656), reducing inequality (Osbourne et al., 2006, pp. 235-242; Shucksmith, 2000a, pp. 208-218) and managing conflict (Prins, 2005, pp. 57-74). Other authors see partnerships as instruments that promote sustainability (Moseley, 2003; Ray, 2000, pp. 163-171), improve understanding and mutual learning (Bovaird, 2004, pp. 199-215; Bull et al., 2008, pp. 701-716; Greer, 2001, pp. 751-770), broaden participation (Reinicke, 1999, pp. 44-58; Reinicke \& Deng, 2000), create new arenas of power and power-relations (Derkzen et al., 2008, pp. 458466), facilitate joint working (Esparcia Perez, 2000, pp. 200-207; Ray, 2000, pp. 163-171), promote social inclusion and tackle social exclusion (Lowndes \& Sullivan, 2004, pp. 51-73). One can add several other advantages to this list, such as means of consulting or involving the public (Lowndes \& Sullivan, 2004, pp. 51-73); effective mechanism for facilitating relationships between different stakeholders (Shortall 2004, p. 113); a forum where local communities can make their voices heard; an agency which can help foster a shared sense of objectives and direction at a local level (Shucksmith, 2000b, p. 40). Generally, LAGs as means of 'getting people together' to share a common goal (local development) and through their 'being close to people' and 'feeling their needs' are frequently perceived as means of addressing social exclusion. The desired outcome of their functioning is therefore social inclusion. 


\section{Methods}

The study covered all 28 LAGs operating in the Kujawsko-Pomorskie voivodship, including: 7 urban LAGs operating in the cities with the population exceeding $20,000^{1}$ and 21 other LAGs operating in urban-rural and rural communes ${ }^{2}$.

As it was mentioned, the aim of the article is to compare the engagement of urban and other LAGs in the voivodship in solving social exclusion problems. To achieve this goal, first of all the LAGs' strategies were analysed in terms of the budget allocated to the implementation of social inclusion projects and the planned effects of these projects. Then, the position of urban LAGs was shown against the background of the others. The formula of normalization of variables is as follows:

$$
Z_{i j}=\frac{X_{i j}}{\bar{X}_{j}}
$$

where: $z_{i j}$ - normalized value of the $j$-th variable for the $i$-th object, $x_{i j}$ - value of $j$-th variable for $i$-th object, $\bar{x}_{j}-$ arithmetic mean of variable $x_{j}$.

Subsequently, using multidimensional comparative analysis methods the LDS social inclusiveness index was built, according to which LAGs were ranked and divided into groups with a similar level of inclusiveness of their strategies. This allowed for a more detailed analysis of the similarities of LAGs in terms of their commitment to solving social exclusion problems.

The LDS social inclusiveness index was calculated on the basis of data and information contained in individual strategies of LAGs. Variables describing the level of LDSs social inclusiveness are presented in table 1 . All of them were stimulants.

The study uses two linear ordering methods: Hellwig method and nonmodel method. In the former standardization was used to normalize variables and in the last it was zero unitarization formula (table 2). In both methods diagnostic variables have not been assigned different weighting factors.

${ }^{1}$ LGD Miasta Brodnicy (LAG1), LGD Grudziądzki Spichlerz (LAG2), LGD Inowroctaw (LAG3), LGD Miasto Wtoctawek (LAG4), LGD Chetmno (LAG5), LGD dla Miasta Torunia (LAG6), Bydgoska LGD Dwie Rzeki (LAG7).

${ }^{2}$ LGD Gminy Powiatu Świeckiego (LAG8), LGD Dolina Drwęcy (LAG9), LGD Bory Tucholskie (LAG10), LGD Dorzecza Zgtowiączki (LAGll), LGD Gmin Dobrzyńskich Region Pótnoc (LAG12), LGD Czarnoziem na Soli (LAG13), LGD Gmin Dobrzyńskich Region Potudnie (LAG14), LGD Nasza Krajna (LAG15), LGR Nasza Krajna i Patuki (LAG16), LGD Patuki Wspólna Sprawa (LAG17), LGD Partnerstwo dla Krajny i Patuk (LAG18), LGD Partnerstwo dla Ziemi Kujawskiej (LAG19), LGD Podgrodzie Toruńskie (LAG20), LGD Pojezierze Brodnickie (LAG21), LGD Razem dla Powiatu Radziejowskiego (LAG22), LGD Sasiedzi wokót Szlaku Piastowskiego (LAG23), LGD Trzy Doliny (LAG24), LGD Vistula Terra Culmensis Rozwój przez Tradycję (LAG25), LGD Zakole Dolnej Wisty (LAG26), LGD Ziemia Gotyku (LAG27), LGD Ziemia Wąbrzeska (LAG28). 
Subsequently, using Spearman's rank correlation coefficient (Rs) it was examined whether rankings of LAGs according to the value of the synthetic variables calculated by two different methods of linear ordering are compatible.

Then, the LDS social inclusiveness index was used to group LAGs into four groups of LAGs with similar level of social inclusiveness of their strategies. The grouping method based on standard deviation was used here and groups are as follows:

- group I (LAGs with a very high level of inclusiveness of LDSs): $d_{i} \in\left(\bar{m}+\sigma, \max _{d i}\right]$

- group II (LAGs with a high level of inclusiveness of LDSs): $d_{i} \in(\bar{m}, \bar{m}+\sigma]$;

- group III (LAGs with a low level of inclusiveness of LDSs): $d_{i} \in(\bar{m}-\sigma, \bar{m}]$;

- group IV (LAGs with a very low level of inclusiveness of LDSs): $d_{i} \in\left[\min _{d i}, \bar{m}-\sigma\right] ;$

where: $d_{i}$ - value of synthetic variable for $i$-th object, $\bar{m}$ - arithmetic mean of synthetic variables, $\sigma-$ standard deviation of synthetic variables, $\max _{d i}-$ maximum value of synthetic variable, $\min _{d i}-$ minimum value of synthetic variable.

\section{Results}

The starting point for comparing the involvement of urban and other LAGs in solving social exclusion problems was the analysis of their LDSs in terms of the budget allocated to the implementation of social inclusion projects and the planned effects of these projects. A summary of this analysis is provided in table 3.

28 LDSs envisaged the support for nearly 18 thousand people at risk of poverty or social exclusion, of which almost $30 \%$ were residents of the seven largest cities. One urban LAG intended to support, on average, 702 people at risk of poverty or social exclusion, and the other LAGs on average 620 people, with half of them less than 350 people.

Most LAGs' strategies assumed that providing support to people at risk of poverty or social exclusion would increase their social activity, but people showing any social activity were, on average, definitely more in LDSs of urban LAGs. The LDS of one urban LAG assumed an increase in social activity as a result of various types of activation projects in, on average, 423 people, which gives a social efficiency indicator of LDS of urban LAG at $60 \%$ (in case of LDSs of other LAGs it was on average 153 people, which gives this indicator at $25 \%$ ). The indicators of potential employment efficiency and employment efficiency were also on an average higher level in the case of urban LAGs compared to the others, however their level was very low.

LDSs of urban LAGs assumed that, as a result of projects aimed at improving professional qualifications and gaining experience through participation in internships, apprenticeships and volunteering as well as a result of other activities (e.g. integration activities leading to building competences and breaking isola- 
tion) activity in the field of seeking a job would take up on average 53 people (in LDSs of the other LAGs 28 on average), while an average of 29 people will find work (12 people respectively). This means that for urban LAGs, the level of potential employment efficiency ratio was on average $8 \%$, and the employment efficiency ratio on average $4 \%$ (for other LAGs $4 \%$ and $2 \%$, respectively).

The total budget of all LAGs allocated to activities aimed at increasing the level of social inclusion amounted to EUR 23.1 million, almost 70\% of which (15.9 EUR mln) was at the disposal of LAGs operating in urban-rural and rural communes. However, the average budget for social inclusion was higher in urban LAGs than in the others. In the first it amounted, on average, to 1.0 EUR mln and in the latter 0.8 EUR mln. In urban LAGs, the amount of support per one person at risk of poverty or social exclusion was also higher. It amounted to EUR 1,471 while in the remaining ones EUR 1,220 on average. It should be noticed that in the case of urban LAGs, the share of funds allocated to combating social exclusion in the total budget allocated to LDS implementation was on average almost 100\%, while in the case of the remaining LAGs this share averaged slightly above $20 \%$. The position of urban and other LAGs determined on the basis of indicators characterizing their activities for social inclusion is presented in chart 1 .

To assess the engagement of each LAG in solving social exclusion problems, for each of them the LDS social inclusiveness index was calculated (using two linear ordering methods), according to which LAGs were ranked in order from the most to the least engaged and divided into 4 groups of LAGs which are the most similar in terms of the engagement. Rs coefficient equalled 0.94 (and was statistically significant), which means almost full compatibility of the two rankings and confirms that, regardless of the ordering method, the positions of LAGs in rankings by inclusiveness of their LDSs are the same. The result of ordering and grouping by non-model method is presented in table 4.

As expected, the highest level of LDS inclusiveness meaning the greatest commitment to solving social exclusion problems was characteristic for all urban LAGs, which allocated all or almost the entire budget planned in their LDSs to social inclusion and for LAG8, in which this share was $86.3 \%$. The latter took first place in the ranking due to the above-average value of support per person. The amount of this support was EUR 7,433 while for urban LAGs it was on average EUR 1,471 and for LAGs operating in other areas (without LAG8) EUR 920. In terms of social efficiency, only LAG2 stood out in the group of LAGs with the highest level of inclusiveness of LDSs - it equalled 92\%. The social efficiency of the strategies of other LAGs in this group ranged from 46\% (LAG8) to $64 \%$ (LAG1).

The group of LAGs with a high level of LDS inclusiveness (high engagement in solving social exclusion problems) included two urban-rural LAGs: LAG13 and LAG15. Their place in the ranking was determined by a very high, but not as in the case of LAG8, level of support intended for the implementation of ac- 
tivities aimed at increasing the degree of social inclusion per person covered by the support. In LAG13 this support was EUR 4,222, and in LAG15 EUR 3,385 . Both LAGs were characterized by a higher than average level of social efficiency indicator (for LAG15 it was 56\%, for LAG13 46\%). The share of funds allocated to social inclusion in the budget for the implementation of the LAG15 strategy was slightly higher than the average share for all LAGs (it was 30.2\%). In LAG13 it was much lower and equalled 16.3\%.

The most numerous group were LAGs with a low level of LDS inclusiveness (low engagement in solving social exclusion problems). With the exception of one LAG, they were characterized by an above average level of social efficiency indicator (it ranged from 51\% in LAG12 to 60\% in LAG19; in LAG26 it was only $27 \%$ ), a relatively low share of the budget allocated for social inclusion in the total budget (from 10.3\% in LAG14 up to 19.2\% in LAG25) and a diversified level of support per person (from EUR 1,222 in LAG26 to EUR 1,790 in LAG17).

In the group of LAGs with a very low level of LDS inclusiveness (very low engagement in solving social exclusion problems) there were six LAGs. The LDSs of LAG16 and LAG24 did not provide for any social inclusion activities or related financial resources. The first is a fisheries partnership with its goals focusing on developing entrepreneurship, increasing tourist attractiveness as well as renewing and protecting the ecological potential of the area covered by the LAG. The second one assumed that one of its goals is to increase the activity of the local community and integrate residents for social inclusion, but the indicators for achieving this goal did not include any connecting social inclusion and the budget did not plan any funds for this purpose. All LAGs in this group were characterized by zero social efficiency, which resulted from the fact that their strategies either did not foresee support for people at risk of poverty or social exclusion at all (such as LAGl6 and LAG24), or did not predict an increase in social activity of people at risk of poverty or social exclusion covered by support in the program (LAG9, LAG20, LAG21, LAG28). The share of funds for social inclusion in the budgets of the latter LAGs was relatively low (ranging from $10.2 \%$ in LAG20 to $17.8 \%$ in LAG9), and the amount of support per person at risk of poverty or social exclusion considerably variable (from EUR 76 in LAG28 to EUR 1,725 in LAG20).

\section{Conclusion}

The study revealed that in the Kujawsko-Pomorskie voivodship urban LAGs are generally much more involved in solving social exclusion problems than the other LAGs. This is demonstrated by the average budget for social inclusion projects of urban and other LAGs, the share of this budget in total budget of their LDSs and by the planned effects of these projects.

In the case of urban LAGs, the average budget for social inclusion amounted to 1.0 EUR mln and in the case of the latter 0.8 EUR mln. Actions to reduce 
poverty and social exclusion were almost all activities envisaged in LDSs of urban LAGs, which is reflected in their budgets in which funds allocated to combating social exclusion constitute almost 100\%. In turn, in the case of the other LAGs the share of such funds in total budget averaged only slightly above $20 \%$. What is more, the LDSs of two of them did not provide for any funds for social inclusion projects.

The LDSs of urban LAGs assumed support for, on average, 702 people at risk of poverty or social exclusion and increasing social activity of, on average, 423 such people, which gives social efficiency indicator of LDS at $60 \%$. Meanwhile, in the case of the LDSs of other LAGs it was, on average, 620 people at risk of poverty or social exclusion intended to support and 153 people with increasing social activity as a result of such support, which gives social efficiency indicator of LDS at 25\%. Among them were four LAGs characterized by zero social efficiency, which resulted from the fact that their LDSs did not assume any increase in social activity of people at risk of poverty or social exclusion covered by financial support.

Apart from the general tendency concerning engagement of urban and other LAGs in solving social exclusion problems, according to which the former are much more involved than the latter, there are two other general remarks to note.

Firstly, the implementation of CLLD in the Kujawsko-Pomorskie voivodship in the 2014-2020 financial perspective was accompanied by the diverse involvement of individual LAGs in actions to reduce the scale of social exclusion. And although urban LAGs stood out positively in this respect, even in their case the effectiveness of planned pro-inclusive activities, measured by the number of people at risk of poverty or social exclusion, whose any social activity has increased, should be considered as low. The effect of implementing CLLD should involve reduction of the scale of social exclusion in the areas of functioning of LAGs. Meanwhile, in the Kujawsko-Pomorskie voivodship the effects of LAGs activities in this area described in their strategies are negligible on a regional scale. This raises the question of efficiency and effectiveness of EU funding for the CLLD instrument and raises concerns in the context of the forthcoming financial perspective, which envisages strengthening the role of the CLLD instrument as a key for local development.

Secondly, despite the above conclusion, urban LAGs undoubtedly stood out from the others LAGs, characterized by greater involvement in the implementation of social inclusive activities. Therefore, it seems that the CLLD instrument tested in the largest cities of the voivodship can be successfully used in other cities in Poland. However, the scope and effectiveness of the actions envisaged therein should be increased.

To sum up, bearing in mind the limitation of the approach used in the article, i.e. covering the LAGs operating in only one voivodship (the only one in Poland in which in the period 2014-2020 CLLD was implemented by the direct method not only in rural areas but also in cities), one can formulate the following general universal recommendation for the next financial perspective: at 
the CLLD programming stage, every effort should be made in order to maximize the social inclusion budget and increase its efficiency by supporting more people at risk of poverty or social exclusion, and create greater opportunities for their activity on the labour market. This recommendation is all the more justified, since the next financial perspective (2021-2027) will reveal the long-term social and economic effects of the 2020 COVID-19 epidemic.

\section{References}

Birolo, L., Secco, L., Da Re, R., \& Cesaro, L. (2012). Multi-system governance within the EU rural development policy: a proposal for LAGs self-evaluation in the Leader program. Politica Agricola Internazionale: International Agricultural Policy, 4. doi:10.22004/ag.econ.153856.

Bovaird, T. (2004). Public-private partnerships: from contested concepts to prevalent practice. International Review of Administrative Sciences, 70(2). doi:10.1177/0020852304044250.

Bull, R., Petts, J., \& Evans, J. (2008). Social learning from public engagement: dreaming the impossible. Journal of Environmental Planning and Management, 51(5). doi:10.1080/09640560802208140.

Bydgoska LGD Dwie Rzeki. (2018). Lokalna strategia rozwoju Stowarzyszenia Bydgoska Lokalna Grupa Dziatania Dwie Rzeki. Retrieved 17.12.2019 from http:// www.lgd.bydgoszcz.pl.

Davidson, J., \& Lockwood, M. (2008). Partnerships as instruments of good regional governance: innovation for sustainability in Tasmania. Regional Studies, 42(5). doi:10.1080/00343400701543165.

Derkzen, P., Franklin, A., \& Bock, B. (2008). Examining power struggles as a signifier of successful partnership working: a case study of partnership dynamics. Journal of Rural Studies, 24(4). doi:10.1016/j.jrurstud.2008.03.010.

Edwards, W.J., Goodwin, M., Pemberton, S., \& Woods, M. (2001). Partnerships, power, and scale in rural governance. Environment and Planning C: Government and Policy, 19(2). doi:10.1068/cl2m.

Esparcia Perez, J. (2000). The Leader programme and the rise of rural development in Spain. Sociologia Ruralis, 40(2). doi:10.1111/1467-9523.00142.

European Committee of the Regions. (2019). The CoR's contribution to the renewed Territorial Agenda, with special emphasis on community-led local development. Retrieved 10.01.2020 from https://cor.europa.eu.

Furmankiewicz, M. (2006). Współpraca międzysektorowa w ramach „partnerstw terytorialnych" na obszarach wiejskich w Polsce. Studia Regionalne i Lokalne, 2(24).

Furmankiewicz, M., Thompson, N., \& Zielińska, M. (2010). Area-based partnerships in rural Poland: the post-accession experience. Journal of Rural Studies, 26(1). doi:10.1016/j.jrurstud.2009.05.001.

Greer, J. (2001). Whither partnership governance in Northern Ireland. Environment and Planning C: Government and Policy, 19(5). doi:10.1068/c0030. 
Hague, M.S. (2004). Governance based on partnership with NGOs: implications for development and empowerment in Bangladesh. International Review of Administrative Sciences, 70(2). doi:10.1177/0020852304044255.

Kapoor, D. (2005). NGO partnerships and the taming of the grassroots in rural India. Development in Practice, 15(2). doi:10.1080/09614520500041864.

Kołomycew, A. (2017). Community-led local development as a new instrument based on the Leader approach. In K. Zajda, A. Kołomycew, Ł. Sykała, \& K. Janas, Leader and community-led local development approach: Polish experiences. Łódź: Uniwersytet Łódzki.

LGD Bory Tucholskie. (2019). Strategia rozwoju lokalnego kierowanego przez spoteczność na lata 2016-2023. Retrieved 17.12.2019 from http:/ /lgd.cerb.pl.

LGD Chetmno. (2018). Lokalna strategia rozwoju na lata 2016-2023 dla obszaru Lokalnej Grupy Dziatania Chetmno. Retrieved 17.12.2019 from http://www. lgdchelmno.pl.

LGD Czarnoziem na Soli. (2015). Lokalna strategia rozwoju na lata 2014-2020. Retrieved 17.12.2019 from http: / czarnoziemnasoli.pl.

LGD dla Miasta Torunia. (2018). Lokalna strategia rozwoju dla obszaru Lokalnej Grupy Dziatania dla Miasta Torunia. Retrieved 17.12.2019 from https: / www. dlatorunia.pl.

LGD Dolina Drwęcy. (2015). Lokalna strategia rozwoju na lata 2014-2020. Retrieved 17.12.2019 from https://www.lgddolinadrwecy.org.pl.

LGD Dolina Zgłowiączki. (2015). Lokalna strategia rozwoju na lata 2014-2020. Retrieved 17.12.2019 from http://www.kujawiaki.pl.

LGD Gmin Dobrzyńskich Region Północ. (2019). Lokalna strategia rozwoju na lata 2016-2023. Retrieved 17.12.2019 from http://elgd.pl.

LGD Gmin Dobrzyńskich Region Południe. (2015). Lokalna strategia rozwoju Stowarzyszenia Lokalna Grupa Dziatania Gmin Dobrzyńskich Region Potudnie. Retrieved 17.12.2019 from https://www.lgddobrzyn.pl.

LGD Gminy Powiatu Świeckiego. (2020). Lokalna strategia rozwoju Lokalnej Grupy Dziatania Gminy Powiatu Świeckiego. Retrieved 17.12.2019 from http:// www.lgdswiecie.pl.

LGD Grudziądzki Spichlerz. (2018). Strategia rozwoju lokalnego kierowanego przez spoteczność na lata 2016-2023. Retrieved 17.12.2019 from http://lgd. grudziadz.pl.

LGD Inowrocław. (2019). Lokalna strategia rozwoju Stowarzyszenia Lokalna Grupa Dziatania Inowroctaw na lata 2014-2020. Retrieved 17.12.2019 from http:// lgd.inowroclaw.pl.

LGD Miasta Brodnicy. (2016). Lokalna strategia rozwoju stowarzyszenia Lokalna Grupa Dziatania Miasta Brodnicy na lata 2014-2020. Retrieved 17.12.2019 from http://lgd.brodnica.pl.

LGD Miasto Włocławek. (2018). Lokalna strategia rozwoju. Retrieved 17.12.2019 from http://lgdwloclawek.pl.

LGD Nasza Krajna. (2015). Strategia rozwoju lokalnego kierowanego przez spoteczność 2016-2023. Retrieved 17.12.2019 from http://www.naszakrajna.org. 
LGD Pałuki Wspólna Sprawa. (2019). Lokalna strategia rozwoju na lata 20142020 Lokalnej Grupy Dziatania Pałuki Wspólna Sprawa. Retrieved 17.12.2019 from https://lgd-paluki.pl.

LGD Partnerstwo dla Krajny i Pałuk. (2018). Strategia rozwoju lokalnego kierowanego przez spoteczność dla obszaru powiatu nakielskiego na lata 2016-2023: aktywna i przedsiębiorcza Dolina Noteci. Retrieved 17.12.2019 from https:// krajna-paluki.cna.org.pl.

LGD Partnerstwo dla Ziemi Kujawskiej. (2019). Lokalna strategia rozwoju: rozwój lokalny kierowany przez spoteczność. Retrieved 17.12.2019 from http://archiwalna.ziemiakujawska.pl.

LGD Podgrodzie Toruńskie. (2019). Lokalna strategia rozwoju Lokalnej Grupy Dziatania Podgrodzie Toruńskie. Retrieved 17.12.2019 from http://www.podgrodzietorunskie.pl.

LGD Pojezierze Brodnickie. (2015). Strategia rozwoju lokalnego kierowanego przez spoteczność. Retrieved 17.12.2019 from http:/ /lgdpojezierzebrodnickie.pl.

LGD Razem dla Powiatu Radziejowskiego. (2019). Lokalna strategia rozwoju kierowana przez spoteczność dla obszaru powiatu radziejowskiego na lata 2016-2023. Retrieved 17.12.2019 from https://lgd.com.pl.

LGD Sąsiedzi wokół Szlaku Piastowskiego. (2020). Lokalna strategia rozwoju na lata 2014-2020 dla Stowarzyszenia Lokalna Grupa Dziatania Sąsiedzi wokót Szlaku Piastowskiego. Retrieved 15.01.2020 from http://lgdsasiedzi.pl.

LGD Trzy Doliny. (2019). Strategia rozwoju lokalnego kierowanego przez spoteczność na lata 2014-2020. Retrieved 17.12.2019 from https: / trzydoliny.eu.

LGD Vistula Terra Culmensis Rozwój Przez Tradycję. (2019). Lokalna strategia rozwoju kierowanego przez społeczność na lata 2016-2023 dla obszaru Lokalnej Grupy Dziatania Vistula Terra Culmensis Rozwój przez Tradycję. Retrieved 17.12.2019 from http://www.lgdvistula.org.

LGD Zakole Dolnej Wisły. (2015). Lokalna strategia rozwoju na lata 2016-2023. Retrieved 17.12.2019 from http:/ / www.zakolewisly.pl.

LGD Ziemia Gotyku. (2019). Lokalna strategia rozwoju kierowanego przez spoteczność dla obszaru Lokalnej Grupy Działania Ziemia Gotyku na lata 20162023. Retrieved 17.12.2019 from http://www.lgd.ziemiagotyku.com.

LGD Ziemia Wąbrzeska. (2019). Lokalna strategia rozwoju obszaru Ziemi Wąbrzeskiej na lata 2016-2022. Retrieved 17.12.2019 from http://www. lgdwabrzezno.pl.

LGR Nasza Krajna i Pałuki. (2015). Lokalna strategia rozwoju Stowarzyszenia Lokalna Grupa Rybacka Nasza Krajna i Pałuki 2014-2020. Retrieved 17.12.2019 from http://lgrnaklo.org.pl.

Lowndes, V., \& Sullivan, H. (2004). Like a horse and carriage or a fish on a bicycle: how well do local partnerships and public participation go together. Local Government Studies, 30(1). doi:10.1080/0300393042000230920.

Marshall, G.R. (2005). Economics for collaborative environmental management. London: Earthscan. 
Ministry of Infrastructure and Development. (2014). Programming of the 20142020 financial perspective: partnership agreement. Retrieved 10.01.2020 from https://www.power.gov.pl.

Moseley, M.J. (Ed.). (2003). Local partnerships for rural development: the European experience. Cambridge: CABI.

Osbourne, S.P., Beattie, R., \& Williamson, A. (2006). The impact of local voluntary and community sector infrastructure on community involvement in rural regeneration partnerships. Public Money and Management, 26(4). doi:10.1111/j.1467-9302.2006.00531.x.

Pollermann, K., Raue, P., \& Schnaut, G. (2014). Multi-level governance in rural development: analysing experiences from Leader for a community-led local development (CLLD). Paper presented at the 54th ERSA Congress, St. Petersburg, Russia.

Prins, E. (2005). Framing a conflict in a community-university partnership. Journal of Planning Education and Research, 25(1). doi:10.1177/0739456X04270370.

Ray, C. (2000). The EU Leader programme: rural development laboratory. Sociologia Ruralis, 40(2). doi:10.1111/1467-9523.00138.

Regulation (EU) No 1303/2013 of the European Parliament and of the Council of 17 December 2013 laying down common provisions on the European Regional Development Fund, the European Social Fund, the Cohesion Fund, the European Agricultural Fund for Rural Development and the European Maritime and Fisheries Fund and laying down general provisions on the European Regional Development Fund, the European Social Fund, the Cohesion Fund and the European Maritime and Fisheries Fund and repealing Council Regulation (EC) No 1083/2006 (OJ L 347).

Reinicke, W.H. (1999). The other world wide web: global public policy networks. Foreign Policy, 117. doi:10.2307/1149561.

Reinicke, W.H., \& Deng, F.M. (2000). Critical choices: the United Nations, networks, and the future of global governance. Ottawa: International Development Research Centre.

Roberts, P. (2003). Partnerships, programmes and the promotion of regional development: an evaluation of the operation of the structural funds regional programmes. Progressin Planning, 59(1). doi:10.1016/S0305-9006(02)00059-4.

Rosenau, P.V. (2000). Public-private policy partnerships. Cambridge: MIT Press.

Scott, A. (2012). Partnerships: Pandora's box or panacea for rural development. Centre for Environment and Society Research Working Paper, 11.

Shortall, S. (2004). Social or economic goals, civic inclusion or exclusion: an analysis of rural development theory and practice. Sociologia Ruralis, 44(1). doi:10.1111/j.1467-9523.2004.00265.x.

Shucksmith, M. (2000a). Endogenous development, social capital and social inclusion: perspectives from Leader in the UK. Sociologia Ruralis, 40(2). doi:10.1111/1467-9523.00143. 
Shucksmith, M. (2000b). Exclusive countryside? Social inclusion and regeneration in rural areas. York: Joseph Rowntree Foundation.

Stoker, G. (1998). Governance as theory: five propositions. International Social Science Journal, 50(155). doi:10.1111/1468-2451.00106.

Ustawa z dnia 20 lutego 2015 r. o rozwoju lokalnym z udziałem lokalnej społeczności [Act of 20 February 2015 on local development with the participation of the local community] (Dz.U. 2015 poz. 378) (Poland).

\section{Acknowledgements}

Author contributions: author has given an approval to the final version of the article.

Funding: this research was funded by the Nicolaus Copernicus University in Torun, Faculty of Economic Sciences and Management statutory sources. 


\section{Appendix}

\section{Table 1.}

\section{Variables describing the level of LDSs social inclusiveness}

\begin{tabular}{ll}
\hline Symbol & \multicolumn{1}{c}{ Description } \\
\hline $\mathrm{X}_{1}$ & $\begin{array}{l}\text { social efficiency of the LDS (in \%), calculated as: the number of people at risk of poverty or social exclu- } \\
\text { sion, whose social activity has increased after leaving the program / number of people at risk of poverty } \\
\text { or social exclusion supported in the program }\end{array}$ \\
$\mathrm{X}_{2}$ & $\begin{array}{l}\text { budget for social inclusion in the total budget for the implementation of the LDS (in \%) } \\
\text { budget for social inclusion per person at risk of poverty or social exclusion supported in the program } \\
\mathrm{X}_{3}\end{array}$ \\
\hline
\end{tabular}

Source: Own preparation.

\section{Table 2.}

\section{Linear ordering methods applied in the study}

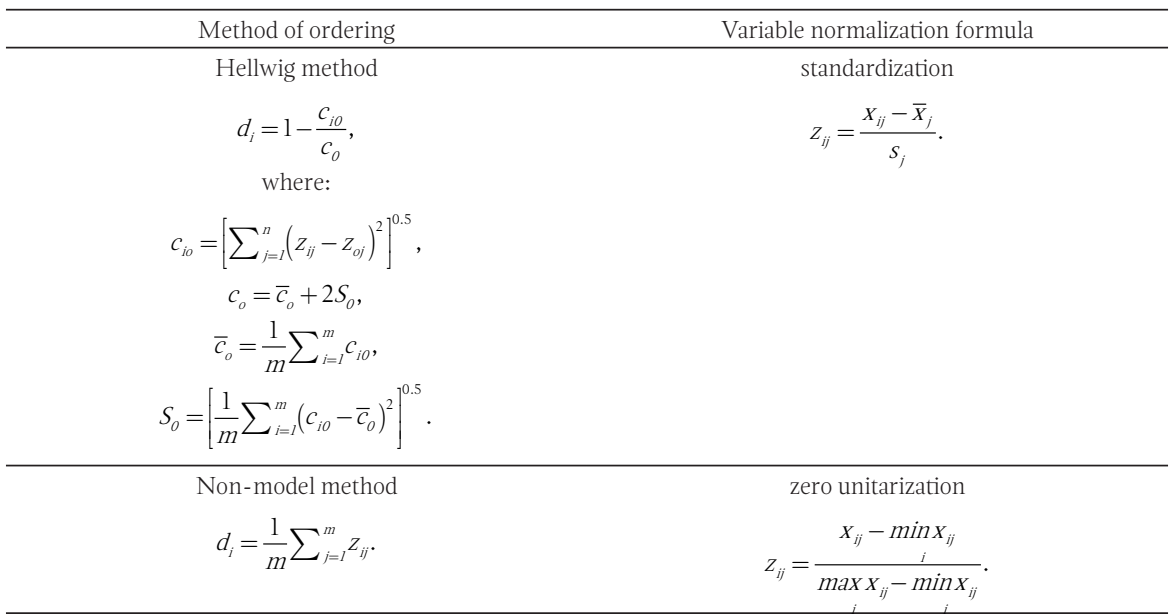

\section{Notes:}

$d_{i}$ - value of synthetic variables for $i$-th object, $z_{i j}$ - normalized value of the $j$-th variable for the $i$-th object, $m$ - number of normalized variables, $x_{i j}$ - value of $j$-th variable for $i$-th object, $\bar{x}_{j}$ - arithmetic mean of variable $x_{i}, s_{i}$ - standard deviation of $j$-th variable, $\max x_{i j}-$ maximum value of $j$-th variable for $i$-th object, $\min x_{i j}-$ minimum value of $j$-th variable for $i$-th object.

Source: Own preparation. 
Table 3.

Data characterizing activities of urban and other LAGs for social inclusion envisaged in their LDSs

\begin{tabular}{|c|c|c|c|c|c|}
\hline Specification & Total & $\begin{array}{l}\text { Mean } \\
\text { value }\end{array}$ & $\begin{array}{l}\text { Minimum } \\
\text { value }\end{array}$ & $\begin{array}{l}\text { Maximum } \\
\text { value }\end{array}$ & Median \\
\hline \multirow{2}{*}{ budget of LDSs for social inclusion (in EUR mln) } & (a) 7.2 & (a) 1.0 & (a) 0.6 & (a) 1.3 & (a) 1.1 \\
\hline & (b) 15.9 & (b) 0.8 & (b) 0 & (b) 4.5 & (b) 0.6 \\
\hline \multirow{2}{*}{$\begin{array}{l}\text { budget of LDSs for social inclusion in the total } \\
\text { budget for the implementation of LDSs (in \%) }\end{array}$} & & (a) 99.96 & (a) 99.5 & (a) 100 & (a) 100 \\
\hline & - & (b) 20.2 & (b) 0 & (b) 86.3 & (b) 15.8 \\
\hline \multirow{2}{*}{$\begin{array}{l}\text { budget of LDSs for social inclusion per person } \\
\text { at risk of poverty or social exclusion supported } \\
\text { in the program (in EUR) }\end{array}$} & - & (a) 1,471 & (a) 1,229 & (a) 2,022 & (a) 1,720 \\
\hline & - & (b) 1,220 & (b) 76 & (b) 7,433 & (b) 1,600 \\
\hline \multirow{2}{*}{$\begin{array}{l}\text { number of people at risk of poverty or social exclu- } \\
\text { sion covered by support in the program }\end{array}$} & (a) 4,915 & (a) 702 & (a) 300 & (a) 1,025 & (a) 750 \\
\hline & (b) 13,012 & (b) 620 & (b) 0 & (b) 5,000 & (b) 350 \\
\hline \multirow{2}{*}{$\begin{array}{l}\text { number of people at risk of poverty or social } \\
\text { exclusion, whose social activity has increased after } \\
\text { leaving the program }\end{array}$} & (a) 2,962 & (a) 423 & (a) 192 & (a) 770 & (a) 349 \\
\hline & (b) 3,218 & (b) 153 & (b) 0 & (b) 439 & (b) 147 \\
\hline \multirow{2}{*}{$\begin{array}{l}\text { number of people at risk of poverty or social exclu- } \\
\text { sion seeking work after leaving the program }\end{array}$} & (a) 369 & (a) 53 & (a) 26 & (a) 76 & (a) 55 \\
\hline & (b) 585 & (b) 28 & (b) 0 & (b) 80 & (b) 26 \\
\hline \multirow{2}{*}{$\begin{array}{l}\text { number of people at risk of poverty or social exclu- } \\
\text { sion working after leaving the program (including } \\
\text { self-employed) }\end{array}$} & (a) 204 & (a) 29 & (a) 14 & (a) 42 & (a) 31 \\
\hline & (b) 282 & (b) 12 & (b) 0 & (b) 33 & (b) 14 \\
\hline \multirow{2}{*}{ social efficiency of LDSs* (in \%) } & \multirow{2}{*}{-} & (a) 60 & (a) 47 & (a) 92 & (a) 55 \\
\hline & & (b) 25 & (b) 0 & (b) 60 & (b) 52 \\
\hline \multirow{2}{*}{ potential employment efficiency of LDSs** (in \%) } & \multirow{2}{*}{ - } & (a) 8 & (a) 7 & (a) 9 & (a) 7 \\
\hline & & (b) 4 & (b) 0 & (b) 40 & (b) 7 \\
\hline \multirow{2}{*}{ employment efficiency of LDSs*** (in \%) } & \multirow{2}{*}{-} & (a) 4 & (a) 4 & (a) 5 & (a) 4 \\
\hline & & (b) 2 & (b) 0 & (b) 13 & (b) 4 \\
\hline
\end{tabular}

Notes:

(a) in the strategies of urban LAGs; (b) in the strategies of urban-rural and rural LAGs; * number of people at risk of poverty or social exclusion, whose social activity has increased after leaving the program / number of people at risk of poverty or social exclusion supported in the program; ${ }^{* *}$ number of people at risk of poverty or social exclusion seeking work after leaving the program / number of people at risk of poverty or social exclusion supported in the program; ${ }^{* * *}$ number of people at risk of poverty or social exclusion working after leaving the program (including self-employed) / number of people at risk of poverty or social exclusion supported in the program. Amounts in PLN contained in LDSs were converted into EUR at the exchange rate of $1 \mathrm{EUR}=4.5$ PLN.

Source: Own preparation based on Bydgoska LGD Dwie Rzeki (2018), LGD Bory Tucholskie (2019), LGD Chełmno (2018), LGD Czarnoziem na Soli (2015), LGD dla Miasta Torunia (2018), LGD Dolina Drwęcy (2015), LGD Dolina Zgłowiączki (2015), LGD Gmin Dobrzyńskich Region Południe (2015), LGD Gmin Dobrzyńskich Region Północ (2019), LGD Gminy Powiatu Świeckiego (2020), LGD Grudziądzki Spichlerz (2018), LGD Inowrocław (2019), LGD Miasta Brodnicy (2016), LGD Miasto Włocławek (2018), LGD Nasza Krajna (2015), LGD Pałuki Wspólna Sprawa (2019), LGD Partnerstwo dla Krajny i Pałuk (2018), LGD Partnerstwo dla Ziemi Kujawskiej (2019), LGD Podgrodzie Toruńskie (2019), LGD Pojezierze Brodnickie (2015), LGD Razem dla Powiatu Radziejowskiego (2019), LGD Sąsiedzi wokół Szlaku Piastowskiego (2020), LGD Trzy Doliny (2019), LGD Vistula Terra Culmensis Rozwój przez Tradycję (2019), LGD Zakole Dolnej Wisły (2015), LGD Ziemia Gotyku (2019), LGD Ziemia Wąbrzeska (2019), LGR Nasza Krajna i Pałuki (2015). 
Table 4.

Local action groups according to the level of inclusiveness of their local development strategies (non-model method of ordering)

\begin{tabular}{lc}
\hline The level of inclusiveness of LDS & Ranking of LAGs \\
\hline $\begin{array}{l}\text { very high } \\
\text { high }\end{array}$ & LAG8, LAG2, LAG1, LAG3, LAG5, LAG7, LAG6, LAG4 \\
LAG15, LAG13 \\
LAG19, LAG10, LAG23, LAG25, LAG11, LAG18, LAG12, LAG17, LAG22, \\
LAG27, LAG14, LAG26 \\
very low \\
LAG9, LAG20, LAG21, LAG28, LAG16, LAG24
\end{tabular}

Note:

In each group LAGs were ordered from the highest to the lowest value of LDS social inclusiveness index.

Source: As in table 3.

\section{Chart 1.}

Normalized indicators characterizing the activities of LAGs for social inclusion: the position of urban LAGs on the background of the others

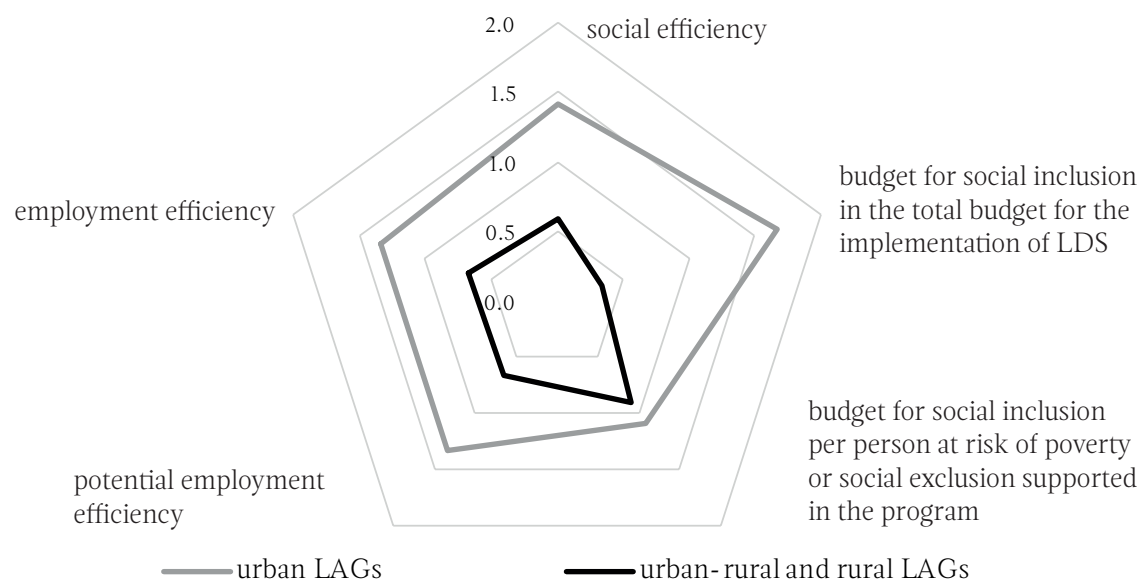

Source: As in table 3. 
